\title{
Biology of the spider mite Eotetranychus egypticus Abdel-Rahman, Ibrahim and Ibrahim (Acari: Tetranychidae) Infesting Citrus Fruits in Egypt with Description of its Immature Stages
}

\author{
Sohier I. Abdel-Rahman; Abla A. Ibrahim and G. A. Ibrahim \\ Plant Protection Research Institute, Agricultural Research Center, Dokki, Giza, Egypt
}

\begin{abstract}
The life cycle of the citrus fruit spider mite Eotetranychus egypticus Abdel-Rahman, Ibrahim \& Ibrahim averaged $13.9 \pm 2.97$ days for female and $15.3 \pm 1.1$ days for male at laboratory conditions of about $25^{\circ} \mathrm{C} \& 60 \%$ R.H. Egg incubation, and total immature stages period averaged $5.7 \pm 0.45 \& 8.6 \pm 2.66$ days for female and $5.8 \pm 0.43 \&$ $9.5 \pm 1.3$ days for male. Oviposition period averaged 13.6 \pm 1.37 days during which average female laid $25.4 \pm 2.19$ eggs with a daily rate $1.9 \pm 0.27$ eggs. Adult female and male longevity averaged $17.3 \pm 0.88$ and $8.6 \pm 1.28$ days respectively. Larva, protonymph and deutonymph were described and illustrated for the first time.
\end{abstract}

Key Words: Tetranychidae, Eotetranychus egypticus, Biology, Morphology, Immature stages.

\section{INTRODUCTION}

No evidence of the genus Eotetranychus Oudemans was noticed in Egypt, except occurrence of Eotetranychus zaheri Zaher, Gomaa and El-Enany (1981). Yet, during this decade, infestation with the recently described species Eotetranychus egypticus Abdel-Rahman ,Ibrahim and Ibrahim (2009) on Citrus spp. (orange, lemon and mandarin) has been existed.

Elmer (1965) reported that E. yumensis (McGregor) was occasionally a serious pest on citrus in certain desert region of southern United States. Only few hosts beside citrus were known but this mite was evidently native to the United States. In (1975), Jeppson et al mentioned that several species of this genus infest citrus trees in different parts of the world. He stated that E. lewisi feeds mostly on citrus fruits causing stippling of the rind, while generally no damage occurring on leaves. Also, it was collected from castor bean, olive and clover. Gutierrez and Halle (1981) reported E. uncatus German infesting apple, in Amsterdam in October 1978. The species, which is a pest of apple and stone fruits in the United States, was reported from Netherlands and Western Europe for the first time.

In California, Bailey \& Olsen (1990) stated that feeding damage by only 5-10 adult $E$ sixmaculates mites per avocado leaf may cause leaf drop. Stevens et al (2001) stated that high population $E$ sixmaculates can cause severe defoliation of avocado trees and subsequent decrease in tree productivity, specially prior to flowering. In 2007, Jamieson and Stevens reported that this mite was considered a serious pest of avocados in New Zeland, causing a purple discolouration along the veins of the underside.

Due to severe infestation of citrus fruits in Sharkia Governorate, Egypt with the recently described species E. egypticus Abdel-Rahman, Ibrahim \& Ibrahim (2009), this papers deals with studying its biology and description of the immature stages.

\section{MATERIALS AND METHODS}

A pure culture of E. egypticus A, I \& I. was maintained under laboratory conditions of about $25^{\circ} \mathrm{C}$ and $60 \%$ R.H., on rind of Citrus mandurensis Lour. Individual rearing was carried out in rectangular plastic cells (modified Manger cells) $10 \mathrm{~cm}$ long, $5 \mathrm{~cm}$ wide and $1 \mathrm{~cm}$ deep, with a circle hole $2.5 \mathrm{~cm}$ in diameter and $1 \mathrm{~cm}$ deep. A disc of rind cut from mandarin orange larger than the cell hole, with a cotton pad, were put under the cell hole and supported by a glass slide of the same size of the rectangular plastic cell. Both glass slid and plastic cell were fasten together by rubber bands. A ring of thin wet cotton was put around the cell edge circle to prevent mite escape. Some females were confined to cells to oviposit for 24 hours, then eggs were left to hatch. Newly hatched larvae were solitary confined individually to empty cells and left to develop. Examination was done daily until reaching the adult stage. Citrus discs were changed when needed. Duration of all stages were calculated. Females were left to oviposit, and number of eggs per day were counted.

Five specimens of each of larvae, protonymphs and deutonymphs were mounted in Hoyer's medium to study the prospected differences which may occur during the mite ontogeny. 


\section{RESULTS AND DISCUSSION}

Life cycle of the recently described species E. egypticus A.I. \& I., which severely infested Citrus spp., at Sharkia Governorate includes egg, larva, two nymphal stages and adult. Duration of the life cycle was completed in $13.9 \pm 2.66 \& 15.3 \pm 1.03$ days for female and male respectively (table 1).

\section{a) Egg:}

The newly deposited egg is globular and orange, then prior to hatching it turns to reddish. Eggs were laid on the surface of citrus fruits specially at the pedical and floral apex. Upon hatching, the egg shell breaks into two halves and emerging larva pushes itself away and starts normal activity. Incubation period lasted $5.7 \pm 0.45 \& 5.8 \pm 0.43$ days for female and male respectively (table 1 ).

Table (1): Mean duration of Eotetranychus egypticus A., I. \& I., different stages under normal laboratory conditions (about $25^{\circ} \mathrm{C} \& 60 \%$ R.H.).

\begin{tabular}{lcc}
\hline \multicolumn{1}{c}{ Mite stages } & \multicolumn{2}{c}{ Duration in days } \\
\cline { 2 - 3 } & (for 29 females) (for 14 males ) \\
\hline Egg incubation & $5.7 \pm 0.45$ & $5.8 \pm 0.43$ \\
Active larva & $1.5 \pm 0.51$ & $1.5 \pm 0.52$ \\
Quiescent larva & $1.0 \pm 0.00$ & $1.4 \pm 0.5$ \\
Active protonymph & $1.5 \pm 0.51$ & $1.9 \pm 0.43$ \\
Ouiescent protonymph & $1.6 \pm 0.67$ & $1.6 \pm 0.5$ \\
Active deutonymph & $1.5 \pm 0.51$ & $1.7 \pm 0.47$ \\
Quiescent deutonymph & $1.5 \pm 0.51$ & $1.5 \pm 0.52$ \\
Immature stages & $8.6 \pm 2.66$ & $9.5 \pm 1.3$ \\
Life cycle & $13.9 \pm 2.93$ & $15.3 \pm 1.1$ \\
Adult longevity & $17.3 \pm 0.88$ & $8.6 \pm 1.28$ \\
Preovipositon & $1.9 \pm 0.35$ & -- \\
Generation period & $15.7 \pm 2.82$ & -- \\
Life span & $31.2 \pm 3.54$ & $23.9 \pm 1.83$ \\
\hline
\end{tabular}

\section{b) Larva:}

Body subcircular measures $258^{\mathrm{m} \mu}$ long including gnathosoma; idiosoma $188^{\mathrm{m \mu}}$ long and $176^{\mathrm{m \mu}}$ wide. Body color orange after hatching then turning to light reddish after feeding. Propodosoma with 3 pairs of setae; hysterosoma with 3 pairs of dorsocentral hysterosomals, 3 pairs of dorsolaterals, one pair of humerals, and two pairs of sacrals but no evidence of clunal seta (Fig 1. A).

Venter with two pairs of ventral setae; anal with two pairs of short setae and two pairs of long paraannal setae (Fig 1. B) . Palp with a simple long seta on genu; tibia with two simple setae and a distinct claw ; palpal trsaus having three simple short setae, rather distinct terminal digit and two solenidia (Fig1.D) Peritreme sausage like, anchor shaped distally, arcute not reaching the stigma (Fig.1C).
Leg chaetaxy as follows: coxae 1-0-0; trochanters 1-1-0; femora 2-2-2; genua 6-4-2; tibiae 6-5-5 and tarsi $6+(2)$ duplex setae $-7+(1)$ duplex seta -6 ; empodium with three long pairs of proximo-ventral hairs (Fig : 1. E.

Larva gave rise to protonymph that lived for an average of $1.5 \pm 0.51 \& 1.5 \pm 0.52$ days for female and male respectively, then entered into quiescent stage for $1 \pm 00 \& 1.5 \pm 0.52$ days for both sexes respectively (table 1).

\section{c) Protonymph:}

Light red and little larger than larva, measures $388^{\mathrm{m} \mu}$ long including gnathosoma; idiosoma $294^{\mathrm{m \mu}}$ long and $247^{\mathrm{m} \mu}$ wide. Dorsum having thirteen pairs of setae; 3 pairs propodosomals, 3 pairs dorsocentral hysterosomals, 3 pairs dorsolaterals, one pair humerals, 2 pairs scrals and one pair clunals (Fig 2. A).

Venter bearing 2 pairs of setae, anal with 2 pairs of short anal setae and 2 long para-annals (Fig 2. B) .Palp with a simple long seta on genu, tibiae having two pairs of simple setae and a distinct claw , tarsus having 3 simple short setae, rather distinct terminal digit and 2 solenidia (Fig 2. D). Preitreme sussage

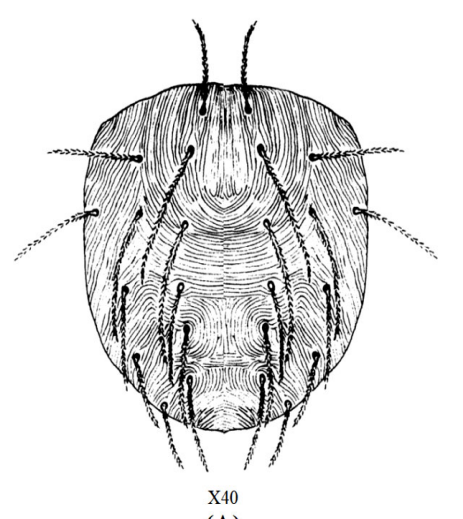

(A)

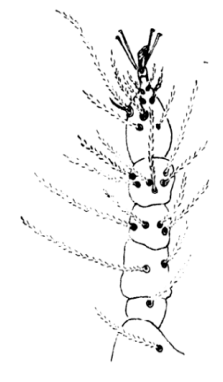

I

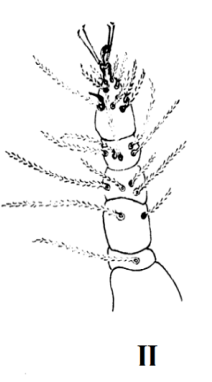

$\mathrm{X} 40$

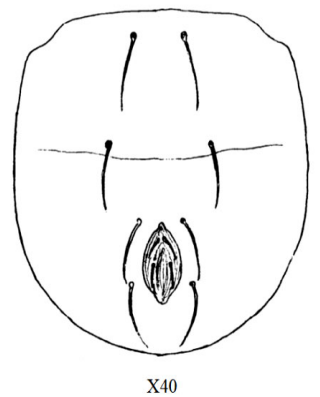

(B)
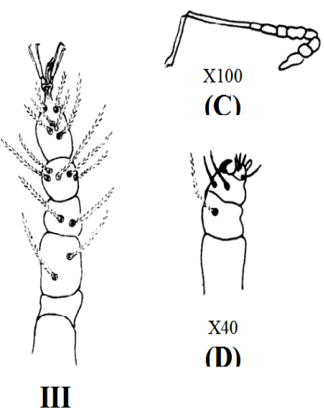

(D)

III
Fig. (1): Eotetranychus egypticus larva: (A) Dorsum,
(B) Venter,
(E) Legs I - III. 


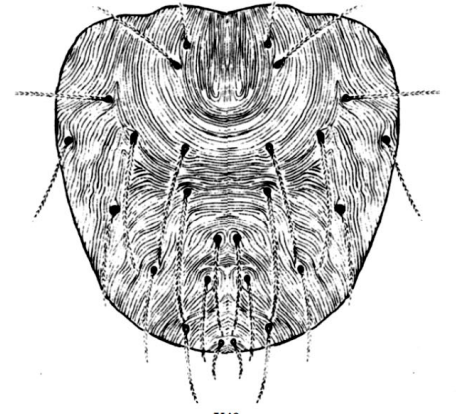

$\mathrm{X} 40$
(A)

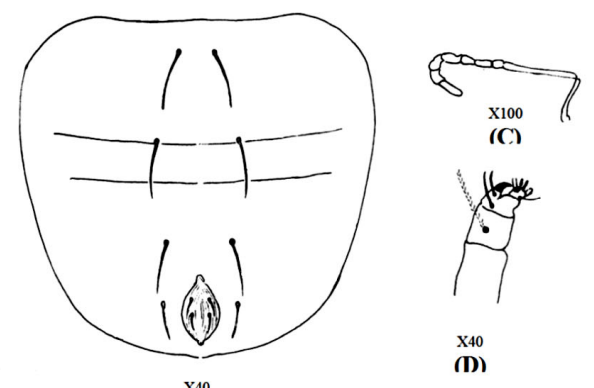

$\mathrm{X} 40$
(B)

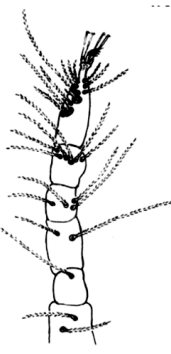

I

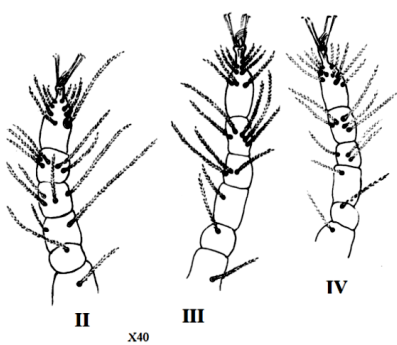

(F)

Fig. (2): Eotetranychus egypticus protonymph: (A) Dorsum, (B) Venter, (C) Peritreme, (D) Palp and (E) Legs I - IV
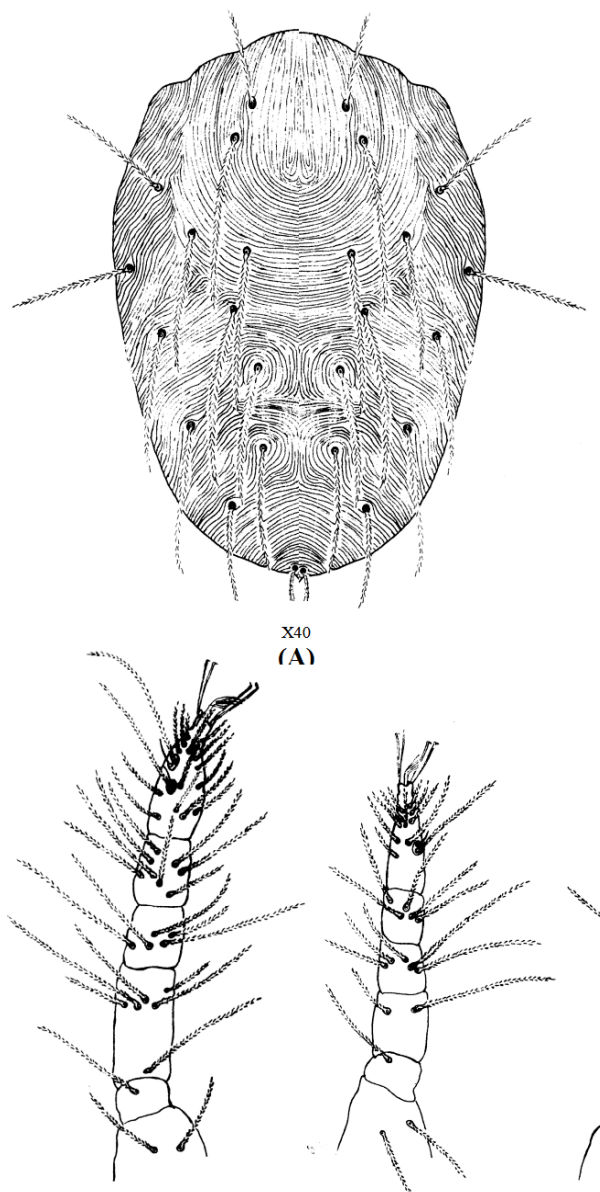

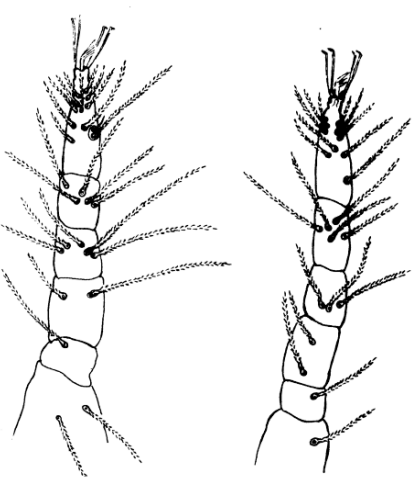

III

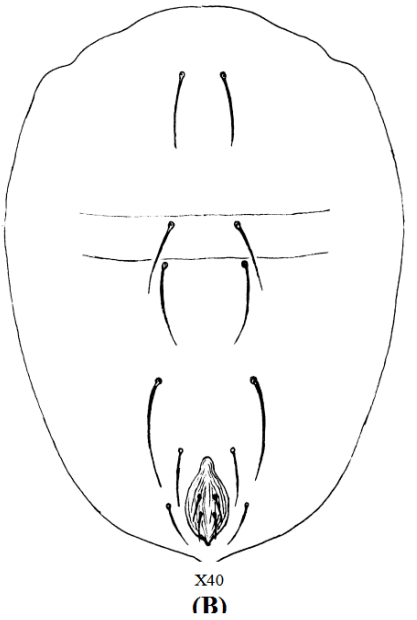

$\sqrt{x+4000}$

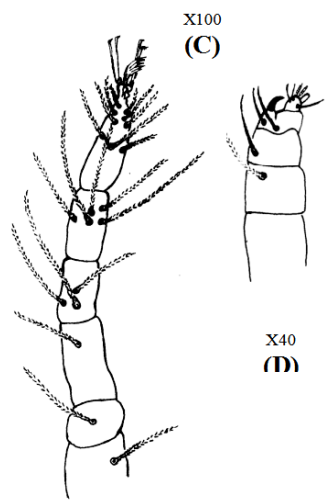

IV

(E)

Fig.3 Eotetranychus egypticus deutonmyph: (A) Dorsum, (B) Venter, (C) Preitreme, (D) Palp and (E) Legs I - IV 
like, anchor shaped (Fig 2. C).

Leg chaetaxy as follows : coxae 2-1-1-1 ; trochanters 1-1-1-1 ; femora 2-2-1-1 ; genua 4-4-3-3 , tibiae $6-5-5-5$; tarsi $8+(2)$ duplex setae $-7+(1)$ duplex seta $-8-9-$; true claw pad like, each with a pair of tenent hairs; empodium consisting of three pairs of proximoventral hairs (Fig 2. E).

Protonymph remained active for $1.5 \pm 0.51$ \& $1.9 \pm 0.43$ days for female and male respectively. The second quiescent period averaged $1.6 \pm 0.67$ days for both sexes (table 1).

\section{d) Deutonymph:}

The newly emerged deutonymph is light reddish. Body oval, $494^{\mathrm{m} \mu}$ long including gnathosoma, idiosoma $353^{\mathrm{m \mu}}$ long and $271^{\mathrm{m} \mu}$ wide. Dorsum with striae, being longitudinal in the medial part of propodosoma, which usually encountered by $\mathrm{u}$-shaped ones, and oblique ones laterally. Stria between $\mathrm{D}_{1}$ and $\mathrm{D}_{2}$ transverse, longitudinal in the median area between $\mathrm{D}_{3}$ and with a circle encountered each, nearly transverse between sacrals. Humerals nearly subequal any of the propodosomals. Dorsum bearing thirteen setae, of which 3 on propodosoma. Setae $\mathrm{D}_{1}-\mathrm{D}_{3}, \mathrm{~L}_{1}-\mathrm{L}_{3}$ and $\mathrm{Sc}_{1}-\mathrm{Sc}_{2}$ exceeding the distance between them, the clunals short. Humerals nearly equal the propodasomals (Fig. 3A). Palp with a simple long seta on the genu, tibia with two simple setae and a distinct claw, palpal tarsus having 3 simple short setae, rather distinct terminal digit and 2 solenidia (Fig. 3D). Peritreme sussage like, anchor shaped distally, (Fig. 3C).

Venter with 3 pairs of setae. Anal having 2 short pairs of setae and 2 pairs of long para-anals (Fig. 3 B).

Leg chaetaxy as follows: coxae $2-2-1-1$; trochanters $1-1-1-1$ femora $6-2-2-1$; genua $5-5-3-3$; tibiae $8-5-5-5$; tarsi $10+(2)$ duplex setae, $10+(1)$ duplex seta $-10-9$; true claws pad like each with a pair of tenent hairs; empodium consisting of three long proximoventral hairs (Fig. 3E).

The active deutonymphal period averaged $1.5 \pm 0.51$ \& $1.7 \pm 0.47$ days for female and male respectively, while the third quiescent period averaged $1.5 \pm 0.51 \& 1.5 \pm 0.52$ days for both sexes respectively (table 1 ).

\section{e) Adult:}

As third quiescence is terminated, the adult female or male emerges through a broken line in the exuviae between propodosoma and hysterosoma.
The posterior end of the body is rounded in the female, while pointed in the male.

Apparntly, life cycle durated little shorter for female (13.9 \pm 2.93 days) than that of male $(15.3 \pm 1.1$ days) but this difference is not significant. On the opposite, adult female longevity was longer for the former $(17.3 \pm 0.88$ days $)$ than the latter $(8.6 \pm 1.28$ days) days. Life span of adult female and male lasted $31.7 \pm 3.54 \& 23.9 \pm 1.38$ days respectively, with average generation period $15.7 \pm 2.82$ days. (Table 1)

In early season, mite individuals were pale greenish attacking citrus fruits causing pale spots on fruit surface. With progressing of the season, color turns to orange then reddish. Feeding causes yellow spots and harm to rinds. Eggs were laid in depressions of floral and pedical fruit apex, which being covered with webs.

\section{Longevity and fecundity:}

Table (2) showed that adult female longevity averaged $17.3 \pm 1.88$ days. Preoviposition period averaged $1.9 \pm 0.35$ days. Oviposition period lasted $13.6 \pm 1.87$ days, during which average female deposited $25.4 \pm 2.19$ eggs, with a daily rate $1.9 \pm 0.27$ eggs.

Table (2): Eotetranychus egypticus A., I. \& I. adult female longevity and fecundity under normal laboratory conditions (about $25{ }^{\circ} \mathrm{C} \& 60 \%$ R.H.).

\begin{tabular}{lc}
\hline \multicolumn{1}{c}{ Period (days) } & Mean \\
\hline Preoviposition & $1.9 \pm 0.35$ \\
oviposition & $13.6 \pm 1.87$ \\
Postoviposition & $1.8 \pm 0.66$ \\
Longevity & $17.3 \pm 0.88$ \\
Fecundity & \\
No. of eggs/female & $25.4 \pm 2.19$ \\
No. of eggs/female / day & $1.9 \pm 0.27$ \\
\hline
\end{tabular}

\section{REFERENCES}

Abel-Rahman, Soheir, I., Ibrahim, Abla, A. \& Ibrahim, G. A. 2009 New group with a new species of the genus Eotetranychus Oudemans (Acari: Tetranychidae) Agric-Res. Rev: 87(2) (In press).

Baily, J. B and Otsen, Y. N. 1996. Control of two ovocado mite species, California Agriculture, March, April: 31-32.

Elmer, H. S., 1965. The yuma spider mite Eotetranychus yamensis on citrus. J. Econ. Entomol. 58 (3): 534-536.

Gutierrez, J. and Helle, W. 1981. Eotetranychus uncatus Garman, a pest of apple new to 
Nethrlands (Acari: Tetranychidae). Entomologische Berichten, Deel . 41, 1. VII. Jamieson, L.E. and Stevens, P.S. 2007. Development rates, longevity and fecundity of six spotted mite (Eotetranychus sexmaculatus) at constant temperatures. New Zealand plant protection $60,72-77$.

Jeppson L. R., Keifer, H. H. \& Baker, E.W. 1975. Mites Injurious to Econom ic Plants: 614 pp.
University of California Press, Berkeley (USA).

Stevens, P. S., Jamieson, L. E. and Cave, J. 2001. Comparative toxicology of pesticides to the six spotted mite Eotetranychus sexmaculatus (Riley) (Acari:Tetranychidae) on avocado. N.Z. Growers' Association Annual Research report 1: 7-11.

Zaher, M. A., Gomaa, E. A. and El-Enany, M. A. 1981 Spider mites of Egypt (Acari: Tetranychidae) Internat. J. Acarol. Vol. 8 (2): 91-114. 